\title{
Taxation of Capital Gains, Tax Avoid- ance and Other Problems Under the Revenue Act of 1934
}

$\mathrm{T}^{\mathrm{m}}$

HE REVENUE ACT of $1934,{ }^{1}$ fundamentally similar to its predecessors, reveals that Congress has not yet courageously faced what are generally recognized as the real problems of income taxation: (a) stability of revenue, (b) uniformity of operation, (c) simphicity of statutory structure, and (d) ease of administration.

There have been mine complete revenue acts ${ }^{2}$ between the adoption of the Sixteenth Amendment and the adoption of the Revenue Act of 1934, each more complex than the last. The conflict between lawyers seeking methods of escape and Congress seeking methods of control has resulted in a steady stream of litigation. ${ }^{3}$ The recorded decisions resulting therefrom have been productive of comparatively little law.4 No attempt has been made to frame our revenue measures so that busmess can know in advance with any certainty what its liabilities to

148 STAT. (1934) 683, 26 U. S. C. A. (1934) § 5001 et seq. The Act became law on May 10, 1934. It is retroactive in that, for income tax purposes, it is applicable to all taxable years beginning after December 31, 1933. Fiscal years ending in 1934 are governed, so far as the rate of tax is concerned, by the Revenuc Act of 1932, 47 STAT. (1932) 191, 26 U. S. C. Supp. VII (1933) \& 101 et seq.

2 The Act of March 3, 1917, 39 STAT. (1917) 1000, is not included since it was nullified $a b$ initio by title II, War Excess Profits Tax, Revenue Act of 1917, 40 STAT. (1917) 300 , adopted October 3, 1917, which Act was effective for the entire calendar year 1917.

3 On the docket of the United States Supreme Court, when it convened at the opening of its October, 1933, term, tax cases occupied a promiment position. U. S. L. Week, October 10, 1933, at 81 . Even more surprising is the number of appeals filed with the United States Board of Tax Appeals, which as of July 1, 1934, exceeded 75,000 . The hoard was created by section 900 of the Revenue Act of 1924, 43 STAT. (1924) 336,26 U. S. C. (1926) § 1211, and was described as "an independent agency in the executive hranch of the governinent." Ibid. $\$ 900(\mathrm{k})$. The board really functions in a quasi-judicial capacity, and since the Revenue Act of 1926, 44 STAT. (1926) 109,26 U. S. C. (1926) $\S 1224$, appeals from its judgments lie direct to the circuit court of appeals in the district wherein the taypayer filed his return, or, by agreement, to the Court of Appeals of the District of Columbia. The right of a taxpayer to appeal from the board to the Court of Appeals of the District of Columbia was denied by section 519 of the 1934 Act.

4 See Development in the Larv-Taxation-1933 (1934) 47 HaRv. L. REv. 1209, 1251, wherein it was said: "Twenty years of the mcome tax have tutored taxpayers and the goverument to a combative subtlety productive of many interesting decisions and a little law. During the period under review, the honors of the combat seemed to rest with the government. Perhaps, where issues of power are involved, that is not undesirable; nevertheless, more desirable would be evidences of a judicious use of the power to produce an internally harmomious and administratively certain tax. The undiminished stream of tax litigation scarcely indicates arrival at that desideratum." 
the government will be. The inflexible rules requiring contests and issues before judicial pronouncement have been steadfastly maintained..$^{\mathbf{5}}$

None of the revenue acts has succeeded in producing a stable revenue. A comparison of our revenue collections with those of Great Britain indicates the full measure of our failure. The average annual revenue from income taxation in the United States during the eleven fiscal years beginning in 1923 and ending in 1933 was $\$ 1,915,000,000$. In Great Britain during the same period it averaged $\$ 1,621,000,000$. In the United States the minimum collected was in $1933, \$ 747,000,000$, while the maximum was collected in 1924 , amounting to $\$ 2,842,000,000$, a variation between the high and low years of approximately $280 \%$, with the mininum $61 \%$ below the average and the maximum $48 \%$ above it. Great Britain's best year was 1923 with collections of $\$ 1,936$,000,000 , and its worst year 1929 with $\$ 1,436,000,000$, a variation of $35 \%$; the maximum annual collections were $19 \%$ above the average and the minimum $11 \%$ below it. ${ }^{6}$ In the United States, revenue was largest when it was least needed. In addition, during the prosperous years of 1924 to 1929 when the tax was most easily paid, the rates were being constantly lowered. ${ }^{7}$ Since 1929 rates have continuously increased and methods of minimizing taxes have waned in inverse ratio.

In connection with this general problem a serious question arises as to whether or not our incoine tax system should take into account profits and losses from the sale of capital assets in deterniming the taxable income of both individuals and corporations. ${ }^{8}$ Some students

\footnotetext{
5 See Arnold, Trial by Combat and the New Deal (1934) 47 Harv. L. Rev. 913. Taxation, touching as it does all business and all business transactions, would seem to constitute an ideal opportunity for judicial review in advance without the necessity of an actual contest.

It is, of course, possible for any taxpayer to write the Bureau of Internal Revenue for a ruling prior to the actual filing of his income tax return. These rulings, however, will not be given by the Bureau until the the transaction has been completed and it is too late for the taxpayer to turn back. Mimeograph 3726, Internal Revenue Cumulative Bulletin, June, 1929, at 332. In addition, the Bureau in such cases, acting in the enviable capacity of judge, jury and advocate, will resolve all doubts in its favor. In any event these rulings are subject to constant reversal within the Bureau and are at no time deemed binding upon it; the only rulings which the Bureau considers authoritative being the so-called Treasury Decisions, which are never issued in cases such as those herein described.

6 See Exhibit "C," Preliminary Report of a Subconmittee of the Committee on Ways and Means, 73d Cong. 2d Sess., (1934) $343 \mathrm{CCH} 6673,6690$.

7 See infra, p. 47 , for a comparison of tax rates prescribed by the present law with those prescribed by prior acts.

8 Statutory definitions of "capital assets" have varied, the definition most commonly used being "property held by the taxpayer for nore than two years" but not including stock in trade, property properly includible in inventory or property held primarily for sale in the course of trade or business. Revenue Act of 1932, 101 (c) (8), 47 STaT. (1932) 191, 26 U. S. C. Supp. VII (1933) § 101 (c) (8). The 1934 Act,
} 
believe that not only should such consideration of capital gains and losses be abolished but that the tax base should concurrently be broadened through the reduction of existing personal exemptions and credit for dependents. At the same time they urge the abolition of the present exemption from tax of the income from federal and state securities and of the salaries of state and municipal employees. ${ }^{\theta}$

This controversial problem merits consideration. Proponents ${ }^{10}$ of the taxation of capital gains base their views on the following grounds:

(1) Such taxation is consistent with our accepted theory of taxation

section 117 (b), makes all property of a taxpayer, with the exceptions above noted, capital assets, regardless of how long held. Hereinafter in speaking of capital assets, the definition used in the 1934 Act will be employed. The 1934 and prior acts deny the capital gain and loss provisions to corporations.

In general, prior to the 1934 Act, capital gains were taxed at a fiat rate of not to exceed $12 \mathrm{x} / 2 \%$ of the amount of the profit realized, regardless of what the rate would have been at prevailing normal and surtax rates, provided, of course, that the capital gain provisions in no case could be employed to increase the tax on the capital profit. Capital losses were deductible in full against other income, or $12 \mathrm{x} / 2 \%$ of the capital loss sustamed was applied against the tax on the other imcome computed without reference to the capital loss. In case of a capital loss, the taxpayer was in all cases required to follow the method which gave the government the most tax. Revenue Act of 1932, § 101 (a) (b), 47 STAT. (1932) 191, 26 U. S. C. Supp. VII (1933) § 101 (a) (b). These various provisions have been productive of much controversy and hitigation.

${ }^{9}$ As of the close of 1933 it was estimated that the total outstanding, interest bearing mdebtedness of the federal, state and local governments amounted to approximately $\$ 40,500,000,000$, on which the annual interest charge was estinated to be approximately $\$ 1,805,000,000$. The aumual loss of revenue to the federal government from these sources is computed at $\$ 160,000,000$. Exhibit "A," Preliminary Report of a Subcommittee of the Committee on Ways and Means, supra note 6, at 6687.

The above report indicates that the great bulk of these tax exempt securities are held by persons with large incomes. In addition, the larger the mcome of the individual, the larger the proportion of his owmership of state and local securities as compared with federal securities. This is obviously due to the fact that state and local securities are totally tax exempt, whereas the federal securities, even though generally more secure, are in many cases only partially exempt.

While the federal government may tax the income from its own securities, it cannot tax interest paid on state and local issues without an anendment to the Federal Constitution. Pollock v. Farmers' Loan \& Trust Co. (1895) 157 U. S. 429, 585. The profit accruing from the sale of such state and local securities is not tax exempt, at least where the securities in question were not originally issued at a discount. Willcuts v. Bum (1931) 282 U. S. 216.

The Treasury naturally does not favor subjecting the mcome from its own securities to unqualified taxation while those of the states, which in a sense compete with federal securities in the open market, are free from taxation. The Treasury unqualifiedly favors the taking of the necessary legal steps to permit it to tax income from all governmental securities. See statement by Acting Secretary Morgenthau before the Judiciary Committee of the House, March 8, 1934, printed in 343 CCH 6808.

10 See Groves, A Tax Policy for the United States (1934) 77 The NEw Repubutc 297, 327, 357; 78 ibid. 12. 
in accordance with ability to pay. Capital gains ordinarily accrue only to those of ample financial resources.

(2) The taxation of capital gains will discourage speculation. The present administration proposes to restore the 1926 price levels. This in turn means inflation with rising prices and consequent profit to the speculator. If these profits are not taxed, the burdens of inflation will fall chiefly on those whon it is sought to aid, namely, those of small ineans.

(3) It is necessary to prevent in the future the great accumulation of corporate saving which was one of the contributing factors to the present depression. Corporations, by continually plowing profits back into the business and declaring tax exempt stock dividends, enable their stockholders to escape all income taxation. If the stockholder needs money, he need only sell certain of his stock and if capital gains are not considered, the profit therefrom is free from tax. This objection necessarily, therefore, also includes the element of tax avoidance.

These arguments proceed from social considerations which, however, encounter serious technical objections.

Those who oppose the taxation of capital gains point to the British system which neither charges its taxpayers with such profits nor permits them to offset such losses against other income. "They hold that the British plan avoids certain defects in our system:

(1) Much of our instability in revenue proceeds from the inclusion in the income base of profits and losses from dealings in capital assets. This is strikingly illustrated by a comparison of individual income tax returns in the United States for the years 1928 and 1931, the first a year of prosperity and the second one of depression. The total tax paid on individual returns for 1928 was $\$ 1,164,000,000$, of which $\$ 534,000$,000 or $46 \%$ represented tax on profits (less losses) from the sale of so-called capital assets exclusive of recurrent or periodic income. Total revenue from individual income tax returns for 1931 was $\$ 241,000,000$, while the net loss in revenue resulting from allowing deductions on account of losses from the sale of capital assets was $\$ 86,000,000$ or a reduction of $26 \%$. An examination of the federal revenues for the past seventeen years shows conclusively that this treatment of gains and losses results in greatly reduced revenue in war and depression years and greatly increased revenue in low tax, prosperous years. ${ }^{12}$

This instability is aggravated by the fact that the taxation of gains and losses gives every taxpayer the right to decide when and how he

11 Konstam, Law of Incono Tax (5th ed. 1931) 122 et seq.

12 See Exhibit "C," Preliminary Report of a Subcommittee of the Committee on Ways and Means, supra note 6. 
shall derive his profit or sustain his loss. Conversely, it is alleged that business is often retarded and the free flow of capital in industry slowed down by the unwillingness of owners to incur large tax liabilities froin sales of their assets.

(2) Much of the income tax avoidance which the 1934 Act purports to prevent is claimed to result from our treatment of capital gains and losses. ${ }^{13}$ The basic fact herewith advanced is that the taxation of current income such as salaries, commissions, fees, dividends, interest, rents and royalties has never encountered serious objections from the taxpayer. He does object, however, to taxation of a large and often unexpected profit realized from the sale of capital assets. The result has been a frequent resort to questionable devices for avoiding realization of profit and securing loss.

(3) It is likewise clained that much of the complexity of our present system arises directly from such statutory provisions ${ }^{14}$ as those covering "exchanges and reorganizations," which were intended to insure the taxation of all capital gains which have actually been realized. ${ }^{15}$ They have instead produced inconsistent results. No problem would arise if assets were always converted into cash. Unfortunately, business is not conducted on such siniple principles.

The real problem arises when the legislative body attempts to define the type of asset conversion which results in taxable income. At first the ideal principle seened to be that taxable income would not arise where property was exchanged for property of a like kind..$^{16}$ This

13 The fraud allegedly practiced by Charles E. Mitchell, Albert M. Wiggins, former Secretary of the Treasury Mellon and many prominent New York investment bankers, arose practically without exception from the deduction by them of capital losses claimed to have resulted from the sale of capital assets. It was a source of surprise to the country at large that various prominent business men paid no tax in 1930,1931 and 1932, their capital losses exceeding their income from all other sources. It was generally overlooked, however, that from 1924 to 1929 capital gains actually sustained, reported and a tax paid thereon in the United States exceeded capital losses in the same period by $\$ 16,000,000,000$, while during 1930 and 1931 capital losses exceeded capital gains by but $\$ 1,000,000,000$. See Exhibit "C," Preliminary Report of a Subcommittee of the Committee on Ways and Means, supra note 6.

14 See Revenue Act of 1934, \$§ 112, 113.

15 When income is actually realized for purposes of tax incidence is a problem of great difficulty. This is true whether current income or profit from sales or exchanges of capital assets is involved. Magill, When is Income Realized? (1933) 46 HaRv. L. Rev. 933.

10 Then Acting Secretary Morgenthau said in his report of December 15, 1933, to the House Ways and Means Committee: "Early decisions of the Supreme Court indicated that in the absence of any specific statutory provisions an exchange of one piece of property for another piece of property might result in taxable gain or deductible loss, as the case may be. In other words, if a farmer traded one horse for another horse, even without any boot, gain or loss should be computed for income tax purposes." (1934) $343 \mathrm{CCH} 6697,6702$. 
approach appeared reasonable, for there might not be cash with which to pay the resulting tax unless there were a sufficient conversion into money or its equivalent. This general principle of like for like was first approved by the Revenue Act of $1921 .^{17}$ Evasions immediately followed as individuals engaged in stock market operations simply traded one stock for another and continuously postponed the reahization of any taxable income. The exchange provisions were accordingly amended ${ }^{18}$ in 1923 to exclude from their operation stocks and bonds, leaving unchanged the balance which covered exchange of "property held for productive use in trade or business or for investment ... solely for property of a like kind." So the law stands today..$^{19}$ Yet there is probably no clearer example of like for like than the exchange of one listed common stock for another histed common stock. The Treasury justifies the present law by declaring that "the exempt exchanges are strictly limited to transactions in which it would be administratively difficult to deternine any gam or loss."20 This is obviously not entirely true, as the transfer of property, regardless of its character, to a corporation in exchange for all of the latter's stock is still free from tax. ${ }^{21}$

A like result has followed from the reorganization provisions. These sections were inserted in the acts not only in recognition of situations where no true tangible profit appeared to be realized, but to facilitate corporate adjustments and reorganizations. As the Treasury aptly said, ${ }^{22}$ these provisions are and have been over specific. "Consequently, astute lawyers could and did arrange what were really sales to take the techmical form of a reorganization within the statutory definition, with resultant loss of revenue."

Actually these exchange and reorganization provisions are now used

$17 \S 202$ (c) (1), 42 STAT. (1921) 227.

18 Act of March 4, 1923, 42 STAT. (1923) 1560.

10 Revenue Act of $1934, \S 112$ (b) (1).

20 Statement of then Acting Secretary Morgenthau, supra note 16, at 6702. The provisions with respect to tax free exchanges and reorganizations herein referred to are not to be construed as mcaning that the profit therefrom forever escapes taxation. The statutes, with certain exceptions, specifically provided that where property was received in connection with a tax free exchange and later disposed of in a taxable transaction, the property so sold had a cost or other basis for the purpose of determining the profit or loss equal to the cost of the original property. Revenue Act of $1934, \& 113$. These provisions did, however, permit indefinite postponement of taxable profit or deductible loss. Needless to say, taxpayers, im all cases where it was to their advantage, utilized these statutory provisions.

21 Revenue Act of $1934, \S 112$ (b) (5). The difficulty of tracing tax free property back to its original owner and making the necessary adjustments to arrive at its true cost has been, and will continue to be, fraught with many administrative difficulties.

22 Statement of then Acting Secretary Morgenthau, supra note 16. 
solely in connection with the determination of capital gains and losses. ${ }^{23}$ If statutory recognition of these gains and losses were eliminated, these sections could be stricken in toto from the Act.

(4) Those who oppose the taxation of capital gains also point out that these capital profits have accrued in most cases over a considerable period of time and therefore declare it unfair to subject them to tax all in one year.

The problein clearly has important social implications involving our whole taxation policy. Despite past experience the mclusion of capital gains and losses in the tax base seems destined to be continued. While the objections to such inclusion are serious, it may be possible to find some less heroic remedy than its entire abolition. ${ }^{24}$

The Revenue Act of 1934

Both the official reports of the various congressional committees and the Treasury recommendations indicated that the primary purposes of the proposed revenue revision resulting in the Revenue Act of 1934 were: (1) prevention of tax avoidance; (2) simplification of the revenue laws; and (3) discovery of possible new sources of revenue, the relative importance of each being in the order named. ${ }^{25}$ The original House bill provided for additional yearly revenue from taxation of $\$ 258,000,000$. The Act as introduced in the Senate imcreased this amount to $\$ 330,000,000$; as finally adopted it provided for additional estimated annual revenue over the 1932 Act of approximately $\$ 417$,000,000 . In connection with the comparison to be hereinafter made the additions as enacted in the final bill may be disregarded, as admittedly they had no connection with so-called tax avoidance.

As a matter of fact, but a sinall portion of the additional revenue to be raised by the 1934 Act will result from the elimination of tax

23 The only provision in those sections of the 1932 Act dealing with exchanges and reorganizations which did not specifically cover so-called capital transactions was section $112(\mathrm{~g})$, which provided that stock or securities received by a corporation in connection with a "reorganization" might under certain circumstances be distributed to the stockholders of that corporation free from tax. This exemption was eliminated from the 1934 Act when it was pointed out in the report of the Ways and Means Committee of the House, dated February 13, 1934, and covering the proposed 1934 Act, that "by this method corporations have found it possible to pay what would otherwise be taxable dividends without any taxes upon their shareholders." (1934) $343 \mathrm{CCH} 6741,6750$.

24 For a brief general discussion of certain of the problems involved in the taxation of capital gains, see Hogan, The Capital Gains Tax (1931) 9 TAX MAG. 165.

25 See Report dated February 13, 1934, of the Ways and Means Committee to accompany H. R. 7835, introduced in the House February 9, 1934, as the Revenue Act of 1934, (1934) 343 CCH 6741, and Report dated March 28, 1934, of Senate Finance Committee to accompany the Senate draft of the Revenue Act of 1934. (1934) $343 \mathrm{CCH} 6813$. 
avoidance. The estimated additional revenue to accrue from the Senate bill came from the following:

1. Capital stock and excess profits tax. $\$ 95,000,000$

2. Increases in estate tax rates $7,000,000$

3. Changes in income tax rate structure. $20,000,000$

4. Administration of depreciation allowances.... $85,000,000$

5. Capital gains and losses.

6. Personal holding compamies (directly or indirectly) $30,000,000$

7. Exchanges and reorganizations. $20,000,000$

8. Consolidated returns $10,000,000$

9. Partnerships $20,000,000$

10. Administrative changes (gasoline and lubricating oil) $5,000,000$

11. Miscellaneous provisions $20,000,000$

Total. $\$ 330,000,000$

The only changes which, strictly speaking, eliminate so-called tax avoidance with resultant additional revenue are the items referred to under 6,7 and 9 , making a total of $\$ 35,000,000$, or slightly more than $10 \%$ of the estimated additional income.

In order to clarify the actual sources of increased revenue as compared with previous acts, the changes made by the 1934 Act may be discussed under the following lieads:

I. Elimination of tax avoidance.

II. Arbitrary disallowances and adjustnients.

III. Increase in tax rate structure.

IV. Depreciation.

V. Admimistrative changes.

In the order above named the revenue producing changes in the Act of 1934 as compared with the Act of 1932 will result in increased revenue as follows:
(a) $\$ 35,000,000$ from items 6,7 and 9 .
(b) $\$ 50,000,000$ from items 5 and 8 .
(c) $\$ 160,000,000$ fron items $1,2,3,10$ and 11.
(d) $\$ 85,000,000$ from item 4 .
Total $\$ 330,000,000$.

Assuming the above classification to be even roughly correct, it follows that the Revenue Act of 1934 is primarily designed to imcrease revenues. Any equalization im taxation burdens is a secondary result. 
The major changes falling within each of the subdivisions above referred to will be separately discussed.

\section{TAX AvOIDANCE}

Although the various congressional committees and the Treasury in their reports refer to tax avoidance, the reader is left with the firm conviction that they are in fact speaking of tax evasion. Actually the two are entirely. different. ${ }^{26}$ The first represents a criminal offense; the second the minimizing of tax liability as provided by statute. With evasion as such we are not here concerned. Avoidance is essentially the result of the failure or neglect on the part of Congress to prevent certain income and certain persons from escaping taxation, which income and persons should properly be subjected to tax.

As previously noted, avoidance in this sense has involved chiefly capital gains and losses. Most of the loopholes in the acts relative to the taxation of capital gains have heretofore been discovered and closed. ${ }^{27}$ Tax avoidance as apphed to capital gains has taken many forms. ${ }^{28}$ Tax avoidance with respect to periodic and recurrent income

26 There are many definitions of avoidance as that term is herem used. In general it may be said that if a device to avoid taxes is carried out by means of legal forms, it constitutes avoidance rather than evasion and is subject to no legal censure. United States v. Isham (1873) 17 Wall. (84 U.S.) 496; Appeal of Pennsylvania Co., etc. (1925) 2 B. T. A. 48.

Justice Holmes' distinction, as laid down in Bullen v. Wisconsin (1916) 240 U. S. 625,630 , is often quoted: "We do not speak of evasion, because, when the law draws a line, a case is on one side of it or the other, and if on the safe side is none the worse legally that a party has availed himself to the full of what the law permits. When an act is condemned as an evasion what is meant is that it is on the wrong side of the line indicated by the policy if not by the mere letter of the law."

More recent cases seem to indicate that if a transaction is what it purports on its face to be and is carried out in good faith and by legal means, it will not be invalid because the motive was to reduce taxes. Fraser v. Nauts (N.D. Ohio 1925) 8 F. (2d) 106; Iowa Bridge Co. v. Commissioner (C. C. A. 8th, 1930) 39 F. (2d) 777, rev'g (1929) 14 B. T. A. 1048.

27 A few examples only need be pointed out. Section 202 (a) (2) of the Revenue Act of 1921, 42 STAT. (1921) 229, required the donce to use the donor's cost or other basis in determining the former's gain or loss from the subsequent sale of the gift property. Section 214 (a) (5) of the same statute'eliminated the possibility of loss deduction from so-called "wash" sales. Section 901 of the 1932 Act imposed for the first time a so-called excise tax of $25 \%$ of the difference between the cost and inarket value of any securities transferred by a domestic person to a foreign corporation or trust. This measure was obviously adopted to eliminate the then more or less common practice of selling capital assets through Canadian or other foreign corporations, where the laws of such foreign countries imposed no tax on capital gains.

28 The so-called exchange and reorganization provisions of the various acts have been repeatedly employed to obtain tax freedom in extrejnely complex transactions. As opposed to these we may examine the simple issue imvolved in Schoenberg v. Commissioner, decided by the Board of Tax Appeals on May 8, 1934. In that case the petitioner and his mother owned all the stock of a corporation. The petitioner sold certain securities at a loss. The same day his corporation bought an equal number of 
is extremely difficult. The courts have ordinarily had no difficulty in solving adversely to the taxpayer most such plans and schemes. ${ }^{29}$ The statutory provision taxing to the grantor of a trust its income, where the grantor retains the power to revest in himself at any time any portion of the income or corpus of the trust, really falls within our second classification of arbitrary disallowances and adjustments. ${ }^{30}$ Tax avoidance as applied to current or periodic income has, however, succeeded in connection with the so-called personal holding company, and the Revenue Act of 1934 has attempted for the first time really to eliminate this evil. ${ }^{31}$

(1) Personal Holding Companies.-The problem here is simple. A family holding company makes sales and accumulates current imcome,

shares of the same securities. Thirty days after the first transaction the petitioner bought the securities from his corporation. The board beld that no legal sale giving rise to a deductible loss bad been made by the petitioner.

In Rosenbloom Finance Corp. v. Commissioner (1932) 24 B. T. A. 763, rev'd, (C. C. A. 3d, 1933) 66 F. (2d) 556, cert. den., (1933) 54 Sup. Ct. 12\%, the taxpayer corporation in 1923 issued its stock for cash to members of the same family. Shortly thereafter the stockholders donated to the corporation certain whiskey warehouse receipts, the present value of which was greatly in excess of their cost. The corporation thereupon sold them and reported no profit from the sale, treating it as neither a gift nor an acquisition of property for stock. The Board of Tax Appeals upheld the corporation's contention. On review, the circuit court of appeals held the transfer to constitute a gift and the corporation's cost to be that of its donors.

29 In Hitner v. Lederer (E.D.Pa. 1926) 14 F. (2d) 991, the corporation conceived the idea of paying its employees' salaries in Liberty Bonds, the income from which was tax exempt. It was claimed that the salaries so paid were likewise exeinpt from taxation. The court perceived no difficulty in over-ruling the taxpayer's contention.

In Lucas v. Earl (1930) 281 U. S. 111, the taxpayer had entered into an agreement in 1901 with his wife in California that one-half of his earnings and profits were bers. They accordingly filed returns, each reporting one-balf thereof. The Commissioner taxed the entire earnings to the husband. In sustaining the Commissioner the Supreme Court said, at 114: "There is no doubt that the statute could tax salaries to those who earned them and provide that the tax could not be escaped by anticipatory arrangements and contracts however skilfully devised to prevent the salary when paid from vesting even for a second in the man who earned it." A different result would now probably be reached due to changes $m$ the California community property laws.

30 Revenue Act of $1934, \S \S 166,167$. These provisions apply even though the trusts are created in good faith and the incoine therefrom is actually paid to and retained by the beneficiaries thereof. That revocable trusts were actually employed for purposes of avoidance is, however, clear beyond doubt. Section 166 of the 1932 Act provided that the income of a trnst was taxable to the grantor where he reserved the right "at any time during the taxable year" to revest in himself title to any part of the corpus. Ingenious attorneys immediately devised trusts which could only be revoked by giving notice a year and a day prior to taking effect. The income of such trusts was held not to be taxable to the grantor. Langley v. Commissioner (C. C. A. 2d, 1932) 61 F. (2d) 796, rev'g (1931) 24 B. T. A. 1156. Section 166 of the 1934 Act remedied this defect.

31 It is not intended, of course, to discuss every change appearing in the 1934 Act. Only those which seem to the writer to be inost important will be referred to. 
much of it tax free because in the form of dividends or tax free interest, and in turn pays out very little or none of its earnings as dividends to its stockholders. In many cases large salaries are paid the owner who deals with the corporation as if its assets were lis individual property. ${ }^{32}$ Prior acts have devised various means of preventing this evil. ${ }^{33}$ In such cases, when the danger became too great the corporation simply liquidated its assets to its stockholders and the stockholders paid a maximum tax on their profits, including undistributed earnings of $12 \mathrm{I} / 2 \%$ thereof under the capital gain provisions, and started the saine procedure all over agaim. ${ }^{34}$ Since this procedure was permissible under the statute and therefore did not constitute tax evasion, it has been well described by the House Ways and Means Committee as constitutimg "perhaps the most prevalent form of tax avoidance."

The 1934 Act inserts in section $351^{36}$ a provision whose drastic nature was necessitated by the situation. If the provision is faulty, it

32 The report of the House Ways and Means Committee, silpra note 23, at 6748, said: "Perhaps the most prevalent form of tax avoidance practiced by individuals with large incomes is the scheme of the "incorporated pocketbook." "

${ }^{33}$ See Revenue Act of 1918, § 220, 40 STAT. (1918) 1057, and similar provisions of subsequent acts. Section 220 of the 1924 and subsequent acts imposed, in addition to the regular corporate tax, a penalty tax of $50 \%$ of undistributed net income. There was no limitation as to source of income or ownership of the stock of the corporation as now appears in section 351 of the 1934 Act. The only thing forbidden was the undue accumulation of surplus with the intent to avoid the imposition of the surtax on the stockholders.

These provisions were infrequently enforced. For a long period the Treasury Department itself doubted their validity. It was always possible for the taxpayer to advance cogent reasons for maintaining a large surplus in his particular busmess. At most this statutory provision constituted an ever present threat to the corporation which accumulated an unduly large surplus.

34 Prior to the Revenue Act of 1934, the liquidation of a corporation was deemed to be a sale by the stockholders of their stock to the corporation, whicb sale was subject to the capital gain provisions. Revenue Act of 1932, § 115 (c); U. S. Treas. Reg. 77 (1932) art. 625.

35 See the report of the House Ways and Means Committee, supra note 23, at 6748 .

36 The section provides for a surtax in addition to the regular corporate tax on the "undistributed adjusted net income of every personal holding company" equal to $30 \%$ of the first $\$ 100,000$ and $40 \%$ of the balance. Personal holding companies are defined as companies (a) $80 \%$ of whose gross income is derived from royalties, dividends, interest, annuities and gains from the sale of securities, and (b) at least $50 \%$ of the stock of which in value is owned during the last half of the taxable year by not more than five individuals. Space will not permit a description of undistributed net income or the various other features involved.

It is interesting to note that this section, as originally adopted by the House, mcluded rent among the sources of income. The striking of this term from the Act by the Senate was finally concurred in by the House.

This measure is similar in many respects to provisions in the British income tax law, which have worked well for some years. Konstam, op. cit. supra note 11, at 332 et seq. 
is probably because it is too specific. Attempts to avoid it will be inevitable, particularly since the elimination of the capital gain provisions as applied to liquidations. ${ }^{37}$ The owners of such corporations cannot now liquidate and begin to operate in a manner approved by statute without subjecting the profit on liquidation to full normal and surtax rates.

In this section of the law each individual year stands alone. Furthermore, the equivalent of section 104 of the 1932 Act is retained in section 102 of the 1934 Act with the difference that the penalty now provided for an undue accumulation of surplus by a corporation, instead of being $50 \%$ of the unlawful accumulation, is $25 \%$ on the first $\$ 100,000$ and $35 \%$ on the balance. Sections 351 and 102 of the 1934 Act are mutually exclusive and it is doubtless loped by Congress that one section will cover any case not falling within the other.

(2) Exchanges and Reorganizations.--One important change in these provisions is that confining the term "reorganization" to a "statutory merger or consolidation."38 It is difficult to see low this change can substantially benefit either the Treasury or the taxpayer. Assuming that the term "statutory" is to be governed by state law, it is well known that the laws of the various states differ materially with respect to mergers and consolidations. That a merger or consolidation is statutory in nature does not imply that no sale in the guise of a genuine reorganization with consequent freedom from tax liability has occurred. $^{39}$ The changed provision has increased rather than simplified the administrative problems of the Treasury, as each examining revenue agent must become an expert in the corporation law of his state or pass the entire problem back to Washington for solution. ${ }^{40}$ The 1934

37 Revenue Act of $1934, \$ 115$ (c). The harshness of this provision may prove to be unwarranted.

38 Ibid., $\$ 112$ (g) (1). It is, of course, understood that unless a "reorganization" as that term is defined by statute occurs, the provisions of this portion of the Act are inapplicable.

39 The explanation for this change appearing in the report of the House Ways and Means Committee, supra note 23 , at 6750 , seems quite unsatisfactory. The real fact would appear to be that elimmation of the reorganization provisions would probably result in diminution of revenue during the depression period as the result of losses which could not otherwise be deducted. In this connection the committee said: "By these limitations the committee believes that it has removed the danger that taxable sales can be cast into the form of a reorganization, . . Furthermore, the retention of the other reorganization provisions will prevent large losses from being established by bondholders and stockholders who receive securities in a newly reorganized enterprise which are substantially the same as their original investments." (Italics added).

${ }^{40}$ It is suggested, if the capital gam provisions must be retained, that there be inserted in the Act by Congress a statement of its policy with respect to these exchange and reorganization provisions. At the same time, the Commissioner and the 
Act has thus failed to accomplish one of its primary objects, namely, simplification.

The other change of note is the elimination from the exchange and reorganization provisions of what was known as section $112(\mathrm{~g})$ of the 1932 Act, which permitted the distribution tax free by a corporation a party to a reorganization of property received in connection with a reorganization. As already pointed out, this section was the only provision in both these portions of the law which was not involved directly with capital gains and capital losses. This provision was eliminated ${ }^{11}$ as constituting an opportunity for avoidance since corporations under those circumstances were permitted to distribute what in fact constituted dividends to their stockholders free from tax.

(3) Installment Sales.-The 1934 Act $^{42}$ permits income from sales of realty and casual sales of personal property to be reported on an installment basis only where the initial payment does not exceed $30 \%$ of the selling price instead of $40 \%$, as was the case with the 1932 law. In addition, gain or loss resulting from the disposition of installment obligations shall be treated as resulting from the sale or exchange of the property in respect of whicl the installment obligation was received. ${ }^{43}$ This in effect preserves for capital gain purposes the status of the asset sold until the entire price lias been received.

(4) Losses on Sales to Members of the Family.-Losses on sales to members of the family will not be allowed, nor will losses on sales between a corporation and a stockholder where such stockholder, including his family, owns more than $50 \%$ in value of the corporation's stock. 14

(5) Allocation of Income and Deductions.-The Commissioner of Internal Revenue is authorized to allocate incoine and expense between two or more organizations, trades or businesses where such allocation is necessary "to prevent evasion of taxes or clearly to reflect the income" of such organizations, trades or businesses. ${ }^{15}$ A similar provision appeared in prior acts. The addition of the word "organizations" in the 1934 Act was doubtless inspired by the fear that the elimination of the

courts should be authorized to look through the form into the substance in order to determine whether or not the particular transaction conforms with the stated policy.

41 See the report of the House Ways and Means Committee, supro note 23.

$42 \S 44$ (b).

$43 \$ 44$ (d).

$14 \$ 24$ (a) (6). The effectiveness of this provision is problematic.

$15 \$ 45$. 
right of corporations to file consolidated returns would force such corporations into other methods of utilizing the losses of their subsidiaries. ${ }^{48}$

The changes affecting avoidance as such, therefore, are in reality comparatively few, and, with the exception of the provision governing personal holding companies, minor in nature. ${ }^{47}$

\section{Arbitrary Disallowances and Adjustments}

This descriptive term, which of course does not appear in any official committee or Treasury report, is here advisedly employed to cover those changes dictated by desire for revenue but not affecting any statutory rate structure. The 1934 Act now gives the taxpayer the least loss or benefit and the government the most tax out of each transaction. There is accordingly no equality of advantage and disadvantage between the taxpayer and the government.

(1) Annuities.-Income from annuities was formerly tax free until the cost of such annunties had been recovered. The 1934 Act taxes an amount thereof equal to $3 \%$ of the cost or other basis of such annuity, the remainder being applied against the cost. ${ }^{48}$

(2) Basis for Loss, Gift Property.-All prior acts, beginning with the Revenue Act of 1921 , required the donee of gift property on the sale thereof to take the donor's cost in determining either profit or loss. In most cases this worked to the government's advantage by increasing the profit. The 1934 Act requires for purposes of determining loss that the donee take either the donor's cost or the value at the date of gift, whichever is lower. The statute requires him, however, to take the

\footnotetext{
46 See comments, infra, p. 46 , with respect to the disallowance of the right of corporations to file consolidated returns.

47 One method of so-called tax avoidance which has been the subject of much discussion and is of peculiar interest in California, is the right now accorded residents of California, based upon the state's community property laws, to divide certain income between husband and wife. This right has been subject to attack as giving a preference to residents of community property states. In commenting on this situation, then Acting Secretary Morgenthau said in his report, supra note 16, at 6706: "This situation not only results in a large loss of revenue to the United States, but also operates most inequitably as between spouses in community and those in nonconumunity property States ...

"The Treasury Department therefore recommends that the committee consider whether a husband and wife living together should not be required to file a single joint return, each to pay the tax attributable to his share of the income. Such a provision has long been in force in other countries."

One may anticipate the enactment into law within the near future of the Treasury Department's recommendation. If so, its validity will be the subject of immediate attack. In this counection, see Hoeper v. Tax Comm. of Wis. (1931) 284 U. S. 206, wherein section 71.05 (2) (d) of the Wisconsin Revised Statutes, which required members of a family residing together to pool their earnings in a single return, was held imvalid.

48 \$22 (b) (2).
} 
donor's basis or cost for determining profit, which is to the government's advantage. 99

(3) Capital Gains and Losses.-The 1934 Act radically alters prior methods of treating capital gains and losses. As noted earlier, it eliminates the requirement of at least two years ownership before the capital gain provision becomes applicable..$^{50}$ All assets now held by the taxpayer, excepting stock in trade or other property which would properly be included in inventory or held primarily for sale to custoners, constitute capital assets. ${ }^{51}$ The statute then provides that a certain percentage of the gain or loss from the sale of such assets shall be taken into consideration depending upon the length of time each asset is held. The shorter the period the larger the percentage. ${ }^{52}$

The 1934 Act then requires all losses to be offset against all gains regardless of the time group into which they may fall. When this has been done, if the losses from the sales of such capital assets exceed such capital gains, they are allowable as a deduction against other incoune only to the extent of $\$ 2,000.53$ Capital gain provisions are denied to corporations but the limitation as to the ainount of loss from the sale of capital assets allowable to corporations is placed at $\$ 2,000$, as is the case with individual taxpayers. ${ }^{54}$

There is no basis of experience upon which to judge the efficacy and fairness of the present capital gain provisions. It is certain, however, that this method of treatinent, while theoretically eliminating the injustice of taxing in one year at prevailing surtax rates a profit which has accumulated over a period of years, ${ }^{55}$ nevertheless apparently leaves unanswered and unsolved the other problems heretofore referred to ${ }^{60}$

\footnotetext{
$49 \$ 113$ (a) (2).

50 See supra note 8 .

$51 \$ 117$ (b).

$52 \$ 117$ (a). The profit or loss sustained is taken into consideration in the following percentages: If owned not more than one year, $100 \%$; if owned between one and two years, $80 \%$; between two and five years, $60 \%$; between five and ten years, $40 \%$; and over ten years, $30 \%$.

The amounts so taken into income, as set forth above, are of course subject to tax at the full normal and surtax rates. In determining the time of ownership of capital assets "tacking" of periods in certain cases is permitted. $\$ 117$ (c). For example, in the case of a gift the time of ownership of the donor may be added to that of the donee in determining the applicable statutory period.

$53 \$ 117$ (d).

$54 \$ 23(j)$.

55 The Acting Secretary in his report, supra note 16, said: "The principal argument against taxing capital gains rests on the grounds that such gains, unlike other incoune, may have accrued over several years; and that to tax such gains at progressive rates in the particular year in which they are realized is to inpose an undue and inequitable burden. This argument has much force." $343 \mathrm{CCH}$ at 6699.

56 The method now proposed, while tending to tax capital gains in a manner akin to the tax imposed on regular or periodic gains, by no means yet reaches that
} 
with respect to capital gains and losses. It is believed by many that the method herein adopted may constitute the first step toward an eventual elimination from our revenue laws of all consideration of capital gams and losses. ${ }^{57}$

(4) Profit from Liquidation of a Corporation.-The capital gain provisions do not apply to the profit accruing to a stockholder from the liquidation of a corporation. The full profit is taxable $100 \%$ to the stockholder regardless of the length of time he lias owned his stock. ${ }^{58}$ This was probably intended to prevent those falling within the provisions of the section aimed at personal holding companies from escaping therefrom by liquidating their compamies and revamping their methods of operation. This limitation, however, is obviously subject to avoidance. The stockholder need only sell his stock to a third person, take advantage of the capital gain provisions, and let his buyer liquidate the company. ${ }^{59}$

(5) Consolidated Returns.-Consolidated returns have been permitted by our various revenue acts for many years, ${ }^{60}$ in accord with the theory of taxing as such a true, economic unit. Modern business and the corporate form of organization often require the division into a number of units of a single business. Each unit nay well be represented by a separate corporation. Some divisions inay earn a profit and others sustain a loss. If the orgamization of the various units was not for the general welfare of the business as a wlole, it would be reasonable to assume that the managers of the business would not create these units. Having done so in good faith and laving complied with the provisions of law relative to consolidation, it is submitted that they slould be pernitted to file a single return including in its four corners all their

desideratum. In this general connection it is at least interesting to speculate as to the possible effect on our depression period of the tendency of security holders to over-reach themselves by their unwillingness to sell securities because of the resulting tax liability.

57 It should be noted that when securities or obligations become totally worthless and no sale or other exchange occurs, the full loss is allowable as heretofore without limitation. The real difficulty in this situation is to establish the required total loss.

$58 \$ 115(c)$.

50 If the purchaser liquidated the corporation immediately and received only the aunount he paid for his stock, no profit would accrue to him. Clearly any measure so liarsh as to be deemed inequitable invites violation.

60 Revenue Act of $1918, \$ 240$, and subsequent acts. More recent acts have given the Counmissioner wide latitude in the issuance of regulations governing consolidated returns and have defined with particularity the prerequisites of consolidation. Revenue Act of $1932, \$ 141$. In addition, this latter Act imposed a penalty of $3 / 4$ of $1 \%$ in increased tax rate for the privilege of filing a consolidated return. This penalty was increased to $1 \%$ by the National Industrial Recovery Act, Public Act No. 67, 73d Cong. 1st Sess. 
profits and all their losses. This is unquestionably sound business and good accounting practice.

The Bureau of Internal Revenue has operated on this basis satisfactorily ${ }^{61}$ for many years. It is true that the heavy losses of recent years have decreased the tax, but this is the result not of consolidated returns but of general business conditions. Nevertheless this loss of revenue has proinpted Congress to eliminate consolidated returns except in the case of railroad corporations, and then only upon the payment of a penalty tax of $2 \%$ over the normal rate. It is subinitted that this measure is aimed, not to counbat tax avoidance, but to increase revenue. ${ }^{62}$ As a matter of fact, it is apt to encourage avoidance and even evasion. Coming as it does in practically the same period when Canada permits consolidated returns for the first time, ${ }^{63}$ it would seen to represent a backward step in revenue legislation and will undoubtedly increase the problems of administration. ${ }^{84}$

(6) Carry-Over of Net Losses Denied.-Prior acts, including that of 1932, permitted both individuals and corporations to carry over into succeeding years net losses sustained in prior years. ${ }^{05}$ This right was eliminated by the National Industrial Recovery $\mathrm{Act}^{6 \mathrm{~B}}$ as well as by the 1934 Act. While this denial was unquestionably dictated by need for revenue, it does not promise to make for stability of revenue. It is contrary to the Enghish rule, which with respect to net losses, has been even more liberal than ours. ${ }^{.7}$ Had the Revenue Act been designed to

61 In commenting on the discretionary power vested in the Coininissioner by more recent acts in his handling of consolidated returns, the then Acting Secretary of the Treasury said in his report, supra note 16: "Congress has previously dealt with the subject of affliated corporations in this way with excellent results so far." $343 \mathrm{CCH}$ at 6702 .

The Treasury was opposed to the abolition of consolidated returns. "For these reasons the Department believes that the abohtion of consolidated returns might well be a backward step which would result in little, if any, additional revenue." Ibid. at 6705 .

62 The Preliminary Report of a Subcommittee of the Committee on Ways and Means, supra note 6 , stated this proposition baldly in the following language: "Your subcommittee is of the opinion that, at least in the first few years, an annual increase in revenue of $\$ 20,000,000$ will result from the proposed elimination of the consohdated return." $343 \mathrm{CCH}$ at 6679 .

63 Dominion of Canada Income War Tax Act, Canada Rev. Stat. (1927) c. 97, as amended by Canada Stats. 1932-33, p. 219.

64 Professor Groves in his series of articles, loc. cit. supra note 10, considering this subject froin a different approach approves the elimination of consolidated returns. As in his discussion of the taxation of capital gains, Professor Groves emphasizes the social considerations involved. It is his contention that complicated corporate structures are definitely anti-social, and that the abolition of consolidated returns would help to discourage thein.

65 Revenue Act of 1932, $\$ 117$.

$66 \S 218$.

67 Konstam, op. cit. supra note 11 , at 174 et seq. 
provide a stable revenue it might have been possible, by confining taxation to recurrent or periodic income, for the government to share the results of depression years with its taxpayers.

(7) Dividends Received by Domestic Corporations from Foreign Corporations.- The 1934 Act subjects dividends so received by doinestic corporations to the full corporate rate regardless of the amount of business such foreign corporations do in the United States. ${ }^{68}$ This, likewise, while classified as an arbitrary adjustment or disallowance, is purely a revenue amendment.

(8) Federal Estate, Inheritance and Gift Taxes No Longer Deductible from Income.-The 1934 Act denies a deduction to any taxpayer of federal estate, inheritance or gift taxes paid. ${ }^{69}$

(9) Limitation on Taxation of Profit from Sale of Oil and Gas Properties Eliminated.-The 1932 Act $^{70}$ limited the tax on the profit from the sale of oil and gas properties to a nuaxinum of $16 \%$ thereof. The 1934 Act eliminates this provision and subjects such sales to the provisions of the capital gain sections.

\section{INCREase IN TAX Rate Structure}

(1) Tax on Income of Individuals. - The 1934 Act was designed to increase rates and at the same time more equitably distribute the burden of taxation. An early announcement was accordingly made that dividends must bear a higher proportion of the tax burden than other forms of income. ${ }^{71}$ A comparison of the 1932 and 1934 Acts shows, however, that the actual increase is neghigible.

In the individual income tax the 1934 Act has achieved commendable sinplicity. The two normal taxes, in effect since 1918, were abolished ${ }^{72}$ with reason, since a progressive surtax renders niore than one normal tax unnecessary. As a result of the abohtion of the second normal tax, the surtax rates now begin at a lower level, namely, $\$ 4,000$. Sinphification has also been achieved by lesseming the number of surtax brackets by $40 \% .^{73}$

The 1934 Act for the first time allows the personal exemption and credit for dependents as a deduction in determining the income subject to surtax as well as to normal $\operatorname{tax}^{74}$ It also restores the credit for

\footnotetext{
$68 \S \S 23$ (p), 25 (a) 1.

$60 \$ 23$ (c) 3 .

$70 \$ 102$.

71 Preliminary Report of a Subcommittee of the Committee on Ways and Means, supra note 6.

72 The Revenue Acts of 1913, 1916, and 1917 provided for but one normal tax.

73 Surtaxes under the 1917 and 1918 Acts began at $\$ 5000$. The 1934 Act contains but 32 surtax brackets. The 1932 Act contained 53 and the Acts of 1918 and

$74 \S \S 12,25$ (b).
} 1921,54 each. 
earned incoine allowed by the various acts from 1924 to 1928 , but omitted by the 1932 Act. $^{75}$ There are no fundamental changes in tax rate structure with respect to individuals. The real problem is to determine the incoine to which the statutory rates are applicable.

(2) Tax on Income of Corporations.- The tax rate levied on the income of corporations remains the same as in the 1932 Act. $^{76}$ Railroad corporations which avail themselves of the privilege of filing consolidated returns must pay $2 \%$ over and above the prevailing rate. ${ }^{77}$

The capital stock tax and excess profits tax levied upon corporations by the National Industrial Recovery Act have been re-enacted in the Revenue Act of $1934 . .^{78}$ This method of taxing corporations seems likely to become increasingly important. The capital stock tax itself is of minor importance, as it is predicated upon the value of the corporation's stock at the comparatively nominal rate of $\$ 1.00$ per thousand. This valuation may be fixed by the corporation at any ainount it chooses. Once fixed, however, it is subject to change only as provided by the statute. ${ }^{79}$ The excess profits tax imposed as a part of the same measure ${ }^{80}$ is, however, of more far reaching importance. This provision imposes an excess profits tax of $5 \%$ in addition to the prevailing corporate rate on all income of the corporation in excess of one-eighth of the declared value of the corporate stock. This tax, when considered with the provisions denying to the corporation the right to change at will the declared value of its capital stock, throws on corporate executives the risk of anticipating their company's taxable income over a long period of time.

(3) Estate Tax.-The Revenue Act of 1934 increased estate taxes very substantially. The 1926 Act imposed a maximum estate tax rate of $20 \% .{ }^{81}$ This was increased by the 1932 Act to $45 \%{ }^{82}$ and by the 1934 Act to $60 \% .{ }^{83}$ In addition, the amendments imposed by the Revenue Acts of 1932 and 1934 eliminated the $80 \%$ credit for state inheritance taxes with respect to the increased tax provided for by those Acts, but continued the credit with respect to the smaller tax imposed by the 1926 Act.

75 Revenue Act of 1934, $\$ 25$ (a) (5). All income up to $\$ 3000$ is considered "earned income," but such incoine, regardless of amount, may not exceed $\$ 14,000$. $\$ 25$ (a) (5) (C).

${ }^{70}$ I. e., $133 / 4 \%$. $\$ 13$.

$77 \S 141(\mathrm{c})$.

$78 \S \S 701-703$.

$79 \$ 701$ (d) (f).

$80 \$ 702$.

81 Revenue Act of 1926, $\$ 301$ (a).

82 Revenue Act of 1932, \$401 (b).

$83 \S 405$. 
(4) Gift Tax.-The 1934 Act increased gift tax rates ${ }^{84}$ to correspond with the increase in estate tax rates. Gift tax rates under the present law reach a maximum of $45 \%$ on gifts in excess of $\$ 10,000,000$, as compared with $60 \%$ in case of decedents' estates.

\section{Depreciation}

Since the Revenue Act of 1918, there has been no substantial statutory change in the provisions authorizing deductions for depreciation..$^{85}$ In all cases the Commissioner of Internal Revenue has, as provided by law, ${ }^{86}$ issued regulations governing the methods of determining the depreciation allowance. Unless clearly contrary to the statute, these regulations have been given the force and effect of law by the courts. ${ }^{87}$

Originally the burden of proof was upon the taxpayer to sustain the reasonableness of the deduction for depreciation as well as other deductions claimed. The regulations issued under the Revenue Act of 1921, however, for the first time provided that the depreciation deducted by the taxpayer must be accepted by the examining revenue agent as proper unless there were clear evidence to the contrary. ${ }^{88}$ This broad latitude given taxpayers imquestionably led to abuses, arising not always from a desire to avoid taxes but often from ultra conservative accounting practices. This problem concerned both Congress and the Treasury Department. $^{89}$ It was finally concluded to leave the statute unchanged in this respect and to amend only the Treasury regulations.

The regulations as now amended impose the burden of proof upon the taxpayer to sustain the depreciation deduction claimed. ${ }^{90}$ It is esti-

$84 \$ 520$.

85 Compare sections 214 (a) (8) and 234 (a) (7) of the Revenue Act of 1918 with section 23 (1) of the 1934 Act.

86 Revenue Act of $1934, \S 62$.

87 Burk-Wagoner Oil Ass'n v. Hopkins (N. D.Tex. 1924) 296 Fed. 492, aff'd, (1925) 269 U. S. 110.

88 U. S. Treas. Reg. 62 (1922) art. 165, issued under the Revenue Act of 1921, provided in part, "While the burden of proof must rest upon the taxpayer to sustain the deduction taken by him, such deductions must not be disallowed unless shown by clear and convincing evidence to be unreasonable." This provision, as a matter of fact, placed the burden of proof on the government.

U. S. Treas. Reg. 77 (1932) art. 205, issued under the Revenue Act of 1932, contained provisions similar to those above quoted.

${ }^{89}$ See letter addressed to the House Ways and Means Committee by the Secretary of the Treasury, January 26, 1934. (1934) $343 \mathrm{CCH}$ 6746. See also the report of then Acting Secretary Morgenthau, supra note 16. The Preliminary Report of a Subcommittee of the Committee on Ways and Means, supra note 6, originally recommended a reduction of $25 \%$ in the depreciation allowance for the years 1934-1936.

90 U. S. Treas. Reg. 77 (1932) art. 205, issued under the Revenue Act of 1932, as above set forth, was amended by T. D. 4422, February 28, 1934. That portion of the Regulations quoted in note 88 , supra, was omitted by T. D. 4422 . In addition, 
mated that these simple changes in the depreciation regulations will produce more additional revenue than any single statutory change made in the 1934 Act, namely, $\$ 85,000,000.91$ Although imposing considerable work upon taxpayers, the new requirements should work satisfactorily.

\section{Administrative Changes}

A number of mteresting administrative changes made in the 1934 Act will be briefly considered.

(1) Statute of Limitations. - The Statute of Limitations for collecting deficiencies in income tax has been extended from two to three years, ${ }^{92}$ as was the case with the 1926 Act. $^{93}$ In this connection, it is provided for the first time that if the return was filed before the due date, the Statute of Limitations begins to run from the due date rather than the filing date. ${ }^{04}$ The government now has five years instead of two within which to bring suit to recover refunds induced by fraud or misrepresentation of a material fact. ${ }^{95}$ The time for filing a claim for refund by the taxpayer is likewise extended from two to three years. ${ }^{00}$

The 1934 Act contains a new provision to the effect that where any taxpayer omits from his return an amount in excess of $25 \%$ of the gross income reported on the return, the government has five years . within which to collect the resulting deficiency. ${ }^{97}$

(2) Board of Tax Appeals. - The time within which a petition may be filed by the taxpayer with the Board of Tax Appeals has been extended from sixty days to ninety days. ${ }^{98}$ Appeals from decisions of the Board of Tax Appeals rendered since the enactment of the 1934 Act may be taken as a matter of right only to the circuit court of appeals in which is located the collector's office in which the return was filed. If the Commissioner of Internal Revenue and the taxpayer so stipulate in writing, however, appeals under the 1934 Act may be taken to any circuit court of appeals or to the Court of Appeals of the District of Columbia. ${ }^{90}$

Dana Latham.

Los Angetes, Calffornia.

this Treasury Decision places upon the taxpayer (1) the burden of preparing proper depreciation schedules and (2) of sustaining the deduction claimed.

01 See estimates of Senate Finance Committee, supra, p. 37.

$92 \$ 275$ (a).

03 Revenue Act of $1926, \$ 275$ (a).

$94 \$ 275$ (d).

$05 \$ \$ 275,502$.

$96 \$ \$ 322$ (b) (1) (d), 504.

$97 \S 275$ (c).

$98 \S \S 272$ (a), 501.

$99 \$ 519$. 